\title{
急性期脳梗塞患者における低骨格筋量の頻度と 背景因子に関する検討
}

\author{
芝崎 謙作 ${ }^{1)}$ 涌谷 陽介 ${ }^{2)}$ 高尾 芳樹 ${ }^{2}$
}

\begin{abstract}
要旨：【背景と目的】急性期脳梗塞患者における低骨格筋量の頻度と関連因子を検討した.【方法】 対象は，2017 年 4 月〜2018 年 12 月に入院した発症 48 時間以内の脳梗塞患者 122 例で, 生体電気イ ンピーダンス法を用いて骨格筋量を評価した。低骨格筋量は，四肢骨格筋指数が男性 $7.0 \mathrm{~kg} / \mathrm{m}^{2}$ 未 満, 女性 $5.7 \mathrm{~kg} / \mathrm{m}^{2}$ 未満と定義した。【結果】低骨格筋量は 82 例 $(67 \%)$ に認めた。多変量解析の結果, 年齢 $>77$ 歳 (オッズ比 3.8, 95\%信頼区間 1.271-11.081，p=0.017)，脳卒中の既往 $(3.7,1.080-12.686$, $0.037), \quad B M I<23.5 \mathrm{~kg} / \mathrm{m}^{2}(11.6,4.023-33.186,<0.001)$ が低骨格筋量の独立した関連因子であった. 【結論】急性期脳梗塞患者の約 $70 \%$ が低骨格筋量を有し, 高齢, 脳卒中の既往, BMI $<23.5 \mathrm{~kg} / \mathrm{m}^{2}$ が関 連因子である。
\end{abstract}

Key words: low skeletal muscle mass, acute ischemic stroke, older age, past history of stroke, body mass index

\section{はじめに}

骨格筋量の低下，および筋力もしくは身体機能の低下 を呈する病態はサルコペニアと名付けられている，様々 な定義と基準が報告されているが，骨格筋量の低下はい ずれの定義でも必須条件である ${ }^{1-3)}$. European Working Group on Sarcopenia in Older People の重症度分類では, 骨格筋量の低下のみをプレサルコペニア, 筋力低下と身 体機能低下の両方を認める場合を重症サルコペニアとし ている ${ }^{1)}$. 要因として, 加齢 (一次性), 活動不足, 疾 患, 栄養不良 (二次性) が挙げられている ${ }^{1)}$. サルコペニ アは, 転倒 ${ }^{4)}$, 骨折 ${ }^{5)}$, フレイル ${ }^{6)}$, quality of life の低下 ${ }^{7)}$,

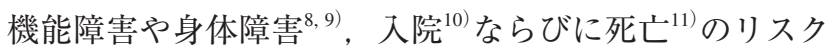
になると報告されている。

亜急性期や慢性期の脳卒中患者を対象としたサルコペ ニアに関する検討が散見される ${ }^{12-14)}$. 脳卒中患者は, 高 齢かつ様々な併存疾患のため, 脳卒中発症前に既に骨格 筋量の低下を有する頻度が多く，また，意識障害や麻疩 等の神経症候, 活動量の低下, 廃用性萎縮, 嚥下障害や 合併症による栄養不良等が加わることでサルコペニアを

\footnotetext{
1) 倉敷平成病院脳卒中内科

2) 倉敷平成病院脳神経内科

(2019 年 3 月 4 日受付, 2019 年 3 月 31 日受理)

doi: $10.3995 /$ jstroke.10724
}

呈すると推測される。しかしながら，急性期脳卒中患者 のデー夕はない，それゆえ，脳卒中急性期の骨格筋量を 評価することは重要である.

四肢骨格筋量の評価には，二重エネルギー X 線吸収 測定法や生体電気インピーダンス法 (bioelectrical impedance analysis: BIA)，CT や MRIを用いた方法がある. BIA 法は，身体を組成する臟器の電気抵抗性の違いを利 用して脂肪量や筋肉量を測定する方法である。信頼性や 妥当性が証明されており，安価で非侵襲性で簡便に測定 でき，外来や寝たきり患者でも評価可能である ${ }^{1,15)}$.

今回，急性期脳梗塞患者において，BIA 法を用いて骨 格筋量を測定し，低骨格筋量の頻度および関連因子につ いて検討する.

\section{対象と方法}

対象は，2017 年 4 月〜2018 年 12 月に当科へ入院した 発症 48 時間以内の急性期脳梗塞患者である. 脳卒中専 門医が，神経学的所見および画像検查 $(\mathrm{CT} \cdot \mathrm{MRI})$ より 脳梗塞と診断した，年齢，性別，血管系危険因子(高血 圧, 糖尿病, 脂質異常症, 心房細動), 既往歴(心不全, 脳卒中, 神経変性疾患, 運動器疾患, 慢性閉塞性肺疾 患), 癌, 入院時 National Institutes of Health Stroke Scale (NIHSS) スコア ${ }^{16)}$, body mass index(BMI), 脳梗塞病型 分類, 血清アルブミン, estimated glomerular filtration rate (eGFR $<60 \mathrm{ml} /$ 分 $\left./ 1.73 \mathrm{~m}^{2}\right)$ ，血清 C-reactive protein(CRP), 
骨格筋量について検討した.

脳梗塞の発症メカニズムを調べるために, 頸部血管超 音波, 経胸壁心臟超音波, 経頭蓋ドプラ, 12 誘導心電 図, 心電図モニター, 24 時間 Holter 心電図, MR angiography などを行った，脳梗塞病型分類は, Trial of Org 10172 in Acute Stroke Treatment 分類を用いた ${ }^{177}$.

血管系危険因子は以下の通り評価した。高血圧 (降圧 薬の服用, 脳梗塞発症前もしくは 2 週間後に収縮期血圧 $140 \mathrm{mmHg}$ 以上, 拡張期血圧 $90 \mathrm{mmHg}$ 以上と定義する), 糖尿病(経口血糖降下薬の服用やインスリンの使用, 空 腹時血糖 $126 \mathrm{mg} / \mathrm{dl}$ あるいは食後血糖 $200 \mathrm{mg} / \mathrm{dl}$ 以上と 定義する)，脂質異常症(高脂血症治療薬の服用，あるい は LDL コレステロール $140 \mathrm{mg} / \mathrm{dl}$ 以上, HDL コレステ ロール $40 \mathrm{mg} / \mathrm{dl}$ 未満, トリグリセライド $150 \mathrm{mg} / \mathrm{dl}$ 以上 のいずれかに該当する場合と定義する), 心房細動は,

12 誘導心電図, 心電図モニター, 24 時間 Holter 心電図 で診断した。神経変性疾患は, 薬物治療を受けている認 知症㧍よびパーキンソン病とした。運動器疾患は, 変形 性脊椎疾患, 脊椎骨折, 変形性股関節症, 大腿骨骨折, 変形性膝関節症とした。

BIA 法(インボデイ社製, InBody S10)を用いて骨格筋 量を測定し, 四肢の筋肉量 (上肢と下肢筋肉量の総和)を 身長 $(\mathrm{m})$ の) 2 乗で除した值を骨格筋指数 (skeletal muscle mass index: SMI) とした。低骨格筋量は, Asian Working Group for Sarcopenia(AWGS)の定義に従い, SMI が男性 $7.0 \mathrm{~kg} / \mathrm{m}^{2}$ 未満, 女性 $5.7 \mathrm{~kg} / \mathrm{m}^{2}$ 未満とした ${ }^{3)}$. AWGS の 診断基準では, 低骨格筋量を必須条件とし, 筋力 (握 力: 男性 $26 \mathrm{~kg}$ 未満, 女性 $18 \mathrm{~kg}$ 未満) もしくは身体機能 (歩行速度 $0.8 \mathrm{~m} /$ 秒以下) の低下を認める場合にサルコペ ニアとしている. 本研究に打いて, 急性期脳梗塞患者 は, 意識障害, 高次脳機能障害, 麻疩等により十分な評 価ができないため, 筋力や身体機能の評価は行っていな い. 全ての検查は, 経験豊かな検査技師が行った。

急性期脳梗塞患者に抢ける低骨格筋量の頻度を調べ た。 また, 低骨格筋量の有無により 2 群に分け, 患者背 景の違いを $\chi^{2}$ 検定, Fisher exact 検定, Mann-Whitney $U$ 検定を用いて比較検討した。低骨格筋量陽性群と陰性群 を識別する各連続変数の至適 cut-off 值を receiver operating characteristics (ROC) 曲線を用いて求めた. 単変量解 析で $\mathrm{p}<0.1$ の因子, ROC 曲線で解析した各連続変数の 至適值を独立因子として多変量解析を行い, $\mathrm{p}<0.05$ を 有意差ありと判断した。統計処理ソフトはSPSS Statistics version 22(IBM)を用いた。

本研究は, 倉敷平成病院倫理委員会の承認を得て実施 した(承認番号 H30-042).

\section{結 果}

発症 48 時間以内の脳梗塞患者 126 例が当科入入院 し，4例が除外された(骨格筋量評価に非協力的 3 例, 早期転院 1 例)。研究期間中に脳梗塞にて再入院した 2 例については初回のデー夕を用いた。 それゆえ，急性期 脳梗塞患者 122 例が登録された。平均年齢 $78.7 \pm 12.3$ 歳, 女性 60 例 (49\%), 入院時 NIHSS スコアは 4(1-9),

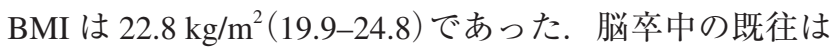
36 例 (30\%), 神経変性疾患の既往は 13 例 (11\%), 運動 器疾患の既往は 27 例 (22\%), 慢性閉塞性肺疾患の既往 は 2 例 (2\%), 癌は 5 例 ( $4 \%$ ) だった。脳梗塞病型分類 は, large-artery atherosclerosis 24 例 (20\%), cardioembolism 22 例 (18\%), small-vessel occlusion 32 例 (26\%), other determined etiology 9 例 (7\%), undetermined etiology 35 例 $(29 \%)$ であった.

入院から骨格筋量測定までの期間は，平均 $1.5 \pm 1.3$ 日 であった. 平均 SMI は $5.9 \pm 1.4 \mathrm{~kg} / \mathrm{m}^{2}$ (男性 $6.8 \pm 1.2 \mathrm{~kg} / \mathrm{m}^{2}$, 女性 $\left.5.1 \pm 1.0 \mathrm{~kg} / \mathrm{m}^{2}\right)$ だった。骨格筋量の低下は 82 例 (67\%) に認めた。低骨格筋量陽性群と陰性群の背景因子 の比較について Table 1 に示す. 年齢 (70(61-83) vs. 84 (76-90) 歳, $\mathrm{p}<0.001)$, 脳卒中の既往 $(15 \%$ vs. $37 \%$, $\mathrm{p}=0.014)$, 神経変性疾患の既往 ( $3 \%$ vs. $15 \%, p=0.034)$ は陽性群で有意に高かった，一方で, BMI(25.7(23.227.5) vs. $\left.21.2(18.8-23.5) \mathrm{kg} / \mathrm{m}^{2}, \quad \mathrm{p}<0.001\right)$ と血清アルブミ ン (4.0(3.8-4.3) vs. 3.8(3.6-4.2) g/dl, p=0.029) は陽性群で 有意に低かった。運動器疾患の既往 (13\% vs. $27 \%$, $\mathrm{p}=0.073$ ）は陽性群で多い傾向を示した。性別, 高血圧, 糖尿病, 脂質異常症, 心房細動，心不全の既往，慢性閉 塞性肺疾患の既往, 癌, 入院時 NIHSS スコア, 脳梗塞 病型分類, $\operatorname{eGFR}\left(<60 \mathrm{ml} /\right.$ 分 $\left./ 1.73 \mathrm{~m}^{2}\right)$, 血清 CRP, 入院か ら骨格筋量測定までの日数は 2 群間で差がなかった。低 骨格筋量陽性群と陰性群を区別する至適年齢， BMI，ア ルブミン值について ROC 曲線を用いて解析した. 結果, 各至適值(感度, 特異度, Area Under the Curve) は, 年齢 77.5 歳 (71\%, 70\%, 0.769), BMI $23.5 \mathrm{~kg} / \mathrm{m}^{2}(76 \%, 75 \%$, $0.850)$, 血清アルブミン $3.85 \mathrm{~g} / \mathrm{dl}(51 \%, 75 \%, 0.620)$ で あった. 多変量解析の結果, 年齢 $>77$ 歳 (オッズ比 3.8 , $95 \%$ 信頼区間 1.271-11.081, $\mathrm{p}=0.017)$, 脳卒中の既往 (3.7, 1.080-12.686, p=0.037), BMI <23.5 kg/m² $(11.6$, 4.023-33.186, $\mathrm{p}<0.001)$ が低骨格筋量の独立した関連因 子であった(Table 2)。これらの因子を用いてリスクスコ アを作成した (年齢 $>77$ 歳 (1 点); 脳卒中の既往 (1 点); $\mathrm{BMI}<23.5 \mathrm{~kg} / \mathrm{m}^{2}$ (2 点)：合計 $0-4$ 点). 各点数における 低骨格筋量の頻度は，0 点では $15 \%$ (3/20人)， 1 点では 
Table 1 Background and clinical characteristics of patients

\begin{tabular}{|c|c|c|c|}
\hline & \multicolumn{2}{|c|}{ Low skeletal muscle mass } & \multirow[b]{2}{*}{$P$-value } \\
\hline & $\begin{array}{c}\text { Negative } \\
n=40\end{array}$ & $\begin{array}{c}\text { Positive } \\
n=82\end{array}$ & \\
\hline Age (years) & $70(61-83)$ & $84(76-90)$ & $<0.001$ \\
\hline Female & $16(40)$ & $44(54)$ & 0.157 \\
\hline Hypertension & $30(75)$ & $60(73)$ & 0.829 \\
\hline Diabetes mellitus & $13(33)$ & $27(33)$ & 0.962 \\
\hline Dyslipidemia & $19(48)$ & $34(41)$ & 0.528 \\
\hline Atrial fibrillation & $5(13)$ & $16(20)$ & 0.335 \\
\hline \multicolumn{4}{|l|}{ Past history } \\
\hline Heart failure & $1(3)$ & $5(6)$ & 0.357 \\
\hline Stroke & $6(15)$ & $30(37)$ & 0.014 \\
\hline Neurodegenerative diseases & $1(3)$ & $12(15)$ & 0.034 \\
\hline Musculoskeletal diseases & $5(13)$ & $22(27)$ & 0.073 \\
\hline COPD & $2(5)$ & 0 & 0.106 \\
\hline Cancer & $1(3)$ & $4(5)$ & 0.469 \\
\hline NIHSS score & $4(2-7)$ & $4(1-9)$ & 0.761 \\
\hline Body mass index $\left(\mathrm{kg} / \mathrm{m}^{2}\right)$ & $25.7(23.2-27.5)$ & $21.2(18.8-23.5)$ & $<0.001$ \\
\hline Stroke subtype & & & 0.325 \\
\hline Large-artery atherosclerosis & $6(15)$ & $18(22)$ & \\
\hline Cardioembolism & $8(20)$ & $14(17)$ & \\
\hline Small-vessel occlusion & $14(35)$ & $18(22)$ & \\
\hline Other determined etiology & $4(10)$ & $5(6)$ & \\
\hline Undetermined etiology & $8(20)$ & $27(33)$ & \\
\hline Serum albumin (g/dl) & $4.0(3.8-4.3)$ & $3.8(3.6-4.2)$ & 0.029 \\
\hline $\mathrm{eGFR}<60 \mathrm{ml} / \mathrm{min} / 1.73 \mathrm{~m}^{2}$ & $15(38)$ & $36(44)$ & 0.501 \\
\hline Serum C-reactive protein (mg/dl) & $0.12(0.06-0.37)$ & $0.11(0.04-0.42)$ & 0.734 \\
\hline $\begin{array}{l}\text { Interval from admission to muscle mass } \\
\text { measurements (days) }\end{array}$ & $1(0-2)$ & $1(1-2)$ & 0.134 \\
\hline
\end{tabular}

Data are presented as medians (interquartile range) or $n(\%)$.

COPD: chronic obstructive pulmonary disease, NIHSS: National Institutes of Health Stroke Scale, eGFR: estimated glomerular filtration rate

$54 \%$ (14/26 人), 2 点では $70 \%$ (16/23 人), 3 点では $91 \%$ (32/35 人), 4 点では $94 \%$ (17/18 人)であった(Fig. 1).

\section{考 察}

急性期脳梗塞患者における骨格筋量の低下は $67 \%$ に 認めた，また，高齢，脳卒中の既往，BMI $<23.5 \mathrm{~kg} / \mathrm{m}^{2}$ が低骨格筋量の独立した関連因子であった。

対象, 骨格筋量の測定方法, 低骨格筋量の定義や基準 によって異なるが，システマティックレビューとメタア
ナリシスによると，一般住民におけるサルコペニアの頻 度は $10 \%$ である ${ }^{18)}$. BIA 法を用いた本邦の検討では, 地域在宅高齢者おける低骨格筋量が 36〜 61\%なのに対 して, サルコペニアは 8〜22\% ${ }^{4,9,19-21)}$ と約 1/3〜1/4 で あった．急性期病棟や長期療養病棟へ入院した高齢者に 関する報告では，低骨格筋量は 82〜 100\% と高率にみら れるが，一方でサルコペニアについては，日常生活動作 の低下や認知機能低下のため握力や歩行速度の評価は困 難であり不明である ${ }^{22-24)}$ ．急性期脳梗塞患者を対象とし 
Table 2 Multivariate logistic regression analysis models for probability of low skeletal muscle mass

\begin{tabular}{lccc}
\hline & OR & $95 \%$ CI & $P$-value \\
\hline Age $>77$ years & 3.8 & $1.271-11.081$ & 0.017 \\
Past history of stroke & 3.7 & $1.080-12.686$ & 0.037 \\
Past history of neurodegenerative disease & 3.5 & $0.336-37.460$ & 0.292 \\
Past history of musculoskeletal disease & 1.9 & $0.503-7.011$ & 0.348 \\
Body mass index $<23.5 \mathrm{~kg} / \mathrm{m}^{2}$ & 11.6 & $4.023-33.186$ & $<0.001$ \\
Serum albumin $<3.8 \mathrm{~g} / \mathrm{dl}$ & 2.0 & $0.592-6.857$ & 0.262 \\
\hline
\end{tabular}

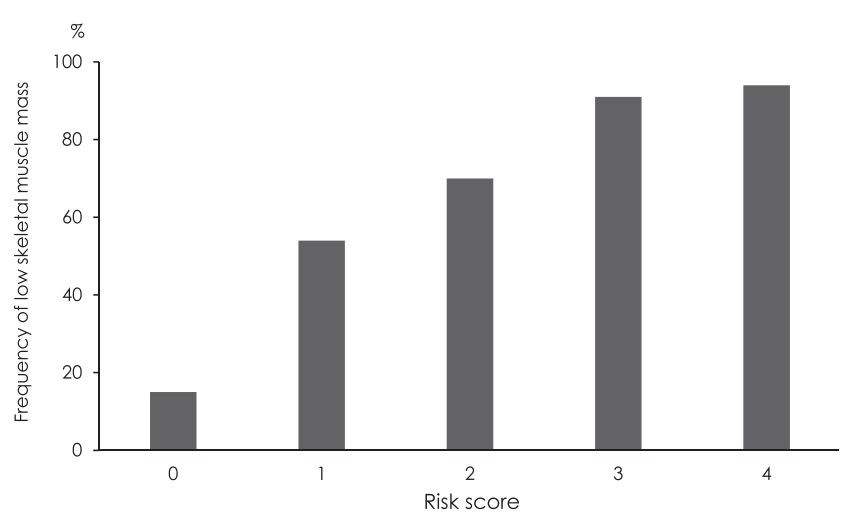

Fig. 1 Relationship between risk score and frequency of low skeletal muscle mass

リスクスコアの各点数における低骨格筋量の頻度は，0 点では $15 \%, 1$ 点では $54 \%, 2$ 点では $70 \%, 3$ 点では $91 \%, 4$ 点では 95\%であった.

た本研究でも骨格筋量の低下は $67 \%$ と高率であり, 少 なくとも 15～20\%は入院時に既にサルコペニアを有す ると推測される. 脳梗塞の発症を契機に, プレサルコペ ニアからサルコペニア, あるいはサルコペニアから重症 サルコペニアの状態へ進展する可能性があり, 脳梗塞急 性期の骨格筋量を評価することの意義は大きいと考え る. 興味深いことに, 近年のランダム化比較試験におい て, サルコペニアを有する脳卒中患者に対する栄養介入 (ロイシン高配合アミノ酸)が, 骨格筋量, 筋力, 身体機 能を有意に増加させることが示された ${ }^{12)}$. しかしなが ら, 骨格筋量が脳梗塞後の転帰に及ぼす影響についての 報告は我々が検索しえた限りではない。 それゆえ, 低骨 格筋量あるいはサルコペニアが脳梗塞後の転帰不良を予 測する因子かどうか明らかにする前向き研究が必要であ ろう.

脳卒中とサルコペニアに関する報告が散見され $ろ^{12-14)}$. Shiraishi らは, 回復期リハビリテーション病棟 へ入院した脳卒中患者において, 発症から中央值 12 日 (10-19) で骨格筋量を評価し, 脳卒中関連のサルコペニ
アの頻度は $53.5 \%$ で, 口腔状態不良が関連因子であると している ${ }^{13)}$. Ryanらは, 脳卒中後 6 力月以上経過した 中高年患者について検討し, サルコペニアの頻度は 14〜18\%と報告した ${ }^{14)}$. しかしながら，これらの検討は 急性期に骨格筋量を評価していないため, 脳卒中関連の サルコペニアかどうかは不明である。脳卒中の急性期と 覀急性期に超音波を用いて大腿四頭筋の厚さを比較した 研究では, 亜急性期に麻痺側で平均 $5.9 \mathrm{~mm}(20.8 \%)$, 非麻痺側で $4.5 \mathrm{~mm}(15.3 \%)$ の減少を認めた ${ }^{25)}$ 。また, 6 カ月以上経過した脳卒中患者における下肢筋の厚さを,

CT, MRI, 超音波, 二重エネルギーX 線吸収測定法で 評価した報告のシステマティックレビューでは, 非麻痺 側と比較し, 麻痺側の大腿筋で 13\%, 下腿筋で 5\%の減 少を認めた ${ }^{26)}$. 本研究結果においても, 脳卒中の既往と 低骨格筋量の関連が明らかであった. Scherbakov らは, 脳卒中関連サルコペニアの発症・進展について, 様々な 併存疾患や, 加龄, 身体不活動, 栄養不良などの発症前 因子だけでなく, 筋線維の変化, 身体機能の左右差, 嚥 下障害や, その後の栄養障害, 廃用性萎縮, 複合的全身 性代謝性変化が含まれ, 多次元的であると述べている27). それゆえ, 脳卒中急性期から慢性期にかけて骨格筋量を 経時的に評価し, 脳卒中関連サルコペニアの頻度および 関連因子を明らかにする前向き研究が必要であろう。

過去の研究から, 筋肉量は加齢に伴い減少することが 示されており ${ }^{28)}$, 高齢者では 1 年で約 $1 \%$ 減少すると報 告されている ${ }^{29)}$. 本研究結果でも, 高齢と低骨格筋量に 関連がみられた。

駒井らは, BMI とサルコペニアの重症度について検 討し, 後期高齢者の普通体重群 (BMI 18.5-25.0)におい てもサルコペニアが $10 \%$ 以上存在することを明らかに している ${ }^{21)}$. 本研究においても, 低骨格筋量を識別する BMI の cut-off 值は $23.5 \mathrm{~kg} / \mathrm{m}^{2}$ と普通体重であった。 そ れゆえ, 普通体重であっても低骨格筋量の存在を念頭に 置かなければならない。 
本研究の限界として, 単施設での検討が挙げられる. また, 筋力や身体機能の評価を行っていないため, 低骨 格筋量を有する患者がプレサルコペニアなのかサルコペ ニア (重症を含む)なのかは不明である. 経過中にサルコ ペニアに関する筋力や身体機能を評価し, サルコペニア の診断(重症度を含む)を行う必要性がある.さらに，本 研究は骨格筋量の評価にBIA 法を用いていることが挙 げられる. BIA 法は, 脱水, 食事摂取, 運動等の影響を 受けるため ${ }^{15)}$, これらの状況下での結果判定には十分注 意が必要であろう.

\section{結 語}

急性期脳梗塞患者の約 $70 \%$ に骨格筋量の低下を認 め, 高齢, 脳卒中の既往, BMI $<23.5 \mathrm{~kg} / \mathrm{m}^{2}$ が低骨格筋 量の独立した関連因子であった。

\section{謝 辞}

骨格筋量の測定をしていただきました検査技師の皆様 に深謝申し上げます。

著者は日本脳卒中学会への COI 自己申告を完了して おり，本論文の発表に関して，開示すべきCOI はない.

\section{参考文献}

1) Cruz-Jentoft AJ, Baeyens JP, Bauer JM, et al: Sarcopenia: European consensus on definition and diagnosis: Report of the European Working Group on Sarcopenia in Older People. Age Ageing 39: 412-423, 2010

2) Fielding RA, Vellas B, Evans WJ, et al: Sarcopenia: an undiagnosed condition in older adults. Current consensus definition: prevalence, etiology, and consequences. International working group on sarcopenia. J Am Med Dir Assoc 12: 249-256, 2011

3) Chen LK, Liu LK, Woo J, et al: Sarcopenia in Asia: consensus report of the Asian Working Group for Sarcopenia. J Am Med Dir Assoc 15: 95-101, 2014

4) Tanimoto $Y$, Watanabe M, Sun W, et al: Sarcopenia and falls in community-dwelling elderly subjects in Japan: Defining sarcopenia according to criteria of the European Working Group on Sarcopenia in Older People. Arch Gerontol Geriatr 59: 295-299, 2014

5) Zhang Y, Hao Q, Ge M, et al: Association of sarcopenia and fractures in community-dwelling older adults: a systematic review and meta-analysis of cohort studies. Osteoporos Int 29: 1253-1262, 2018

6) Spira D, Buchmann N, Nikolov J, et al: Association of low lean mass with frailty and physical performance: A comparison between two operational definitions of sarcopenia-data from the Berlin Aging Study II (BASE-II). J Gerontol A Biol Sci Med Sci 70: 779-784, 2015

7) Beaudart C, Reginster JY, Petermans J, et al: Quality of life and physical components linked to sarcopenia: The SarcoPhAge study. Exp Gerontol 69: 103-110, 2015
8) Janssen I, Heymsfield SB, Ross R: Low relative skeletal muscle mass (sarcopenia) in older persons is associated with functional impairment and physical disability. J Am Geriatr Soc 50: 889896, 2002

9) Tanimoto Y, Watanabe M, Sun W, et al: Association between sarcopenia and higher-level functional capacity in daily living in community-dwelling elderly subjects in Japan. Arch Gerontol Geriatr 55: e9-13, 2012

10) Zhang $X$, Zhang $W$, Wang $C$, et al: Sarcopenia as a predictor of hospitalization among older people: a systematic review and meta-analysis. BMC Geriatr 18: 188, 2018

11) Zhang $X$, Wang $C$, Dou $Q$, et al: Sarcopenia as a predictor of all-cause mortality among older nursing home residents: a systematic review and meta-analysis. BMJ Open 8: e021252, 2018

12) Yoshimura $Y$, Bise $T$, Shimazu $S$, et al: Effects of a leucine-enriched amino acid supplement on muscle mass, muscle strength, and physical function in post-stroke patients with sarcopenia: A randomized controlled trial. Nutrition 58: 1-6, 2019

13) Shiraishi A, Yoshimura Y, Wakabayashi H, et al: Prevalence of stroke-related sarcopenia and its association with poor oral status in post-acute stroke patients: Implications for oral sarcopenia. Clin Nutr 37: 204-207, 2018

14) Ryan AS, Ivey FM, Serra MC, et al: Sarcopenia and physical function in middle-aged and older stroke survivors. Arch Phys Med Rehabil 98: 495-499, 2017

15) Janssen I, Heymsfield SB, Baumgartner RN, et al: Estimation of skeletal muscle mass by bioelectrical impedance analysis. J Appl Physiol 89: 465-471, 2000

16) Lyden P, Brott T, Tilley B, et al: Improved reliability of the NIH Stroke Scale using video training. NINDS TPA Stroke Study Group. Stroke 25: 2220-2226, 1994

17) Adams HP, Bendixen BH, Kappelle LJ, et al: Classification of subtype of acute ischemic stroke. Definitions for use in a multicenter clinical trial. TOAST. Trial of Org 10172 in Acute Stroke Treatment. Stroke 24: 35-41, 1993

18) Shafiee G, Keshtkar A, Soltani A, et al: Prevalence of sarcopenia in the world: a systematic review and meta- analysis of general population studies. J Diabetes Metab Disord 16: 21, 2017

19) Yamada M, Nishiguchi S, Fukutani N, et al: Prevalence of sarcopenia in community-dwelling Japanese older adults. J Am Med Dir Assoc 14: 911-915, 2013

20）谷口 優, 清野 諭, 藤原佳典ら：地域在住高齢者にお ける身体機能・骨格笳量・サルコペニアと認知機能との 横断的・縦断的な関連性. 日老医誌 52: 269-277, 2015

21）駒井さつき, 渡邊 裕, 藤原佳典ら：日本の地域在住高 齢者における栄養状態とサルコペニア重症度の関連性の 検討一BMI，Alb，体重減少の有無との関連一。日老医誌 53: 387-395, 2016

22) Maeda K, Akagi J: Sarcopenia is an independent risk factor of dysphagia in hospitalized older people. Geriatr Gerontol Int 16 : 515-521, 2016

23) Maeda K, Akagi J: Cognitive impairment is independently associated with definitive and possible sarcopenia in hospitalized older adults: The prevalence and impact of comorbidities. Geriatr Gerontol Int 17: 1048-1056, 2017

24) Yamanouchi A, Yoshimura Y, Matsumoto $Y$, et al: Severely decreased muscle mass among older patients hospitalized in a long-term care ward in Japan. J Nutr Sci Vitaminol 62: 229234, 2016 
25) Nozoe M, Kanai M, Kubo H, et al: Changes in quadriceps muscle thickness, disease severity, nutritional status, and C-reactive protein after acute stroke. J Stroke Cerebrovasc Dis 25: 24702474,2016

26) Hunnicutt JL, Gregory CM: Skeletal muscle changes following stroke: a systematic review and comparison to healthy individuals. Top Stroke Rehabil 24: 463-471, 2017

27) Scherbakov N, Sandek A, Doehner W: Stroke-related sarcope- nia: specific characteristics. J Am Med Dir Assoc 16: 272-276, 2015

28）谷本芳美, 渡辺美鈴, 河野 令ら：日本人筋肉量の加齢 による特徵. 日老医誌 47: 52-57, 2010

29) Goodpaster BH, Park SW, Harris TB, et al: The loss of skeletal muscle strength, mass, and quality in older adults: the health, aging and body composition study. J Gerontol A Biol Sci Med Sci 61: 1059-1064, 2006

\title{
Abstract \\ Frequency and background factors of low skeletal muscle mass in acute ischemic stroke patients
}

\author{
Kensaku Shibazaki, M.D., Ph.D., ${ }^{1)}$ Yousuke Wakutani, M.D., Ph.D., ${ }^{2)}$ and Yoshiki Takao, M.D., Ph.D. ${ }^{2)}$
}

${ }^{1)}$ Department of Stroke Medicine, Kurashiki Heisei Hospital

${ }^{2}$ Department of Neurology, Kurashiki Heisei Hospital

Background and Purpose: The aim of this study was to investigate the frequency of low skeletal muscle mass in acute ischemic stroke patients and to clarify the factors associated with them. Methods: We enrolled 122 patients with ischemic stroke within $48 \mathrm{~h}$ of onset between April 2017 and December 2018. Skeletal muscle mass was measured by bioelectric impedance analysis. We defined low skeletal muscle mass as skeletal muscle mass index $<7.0 \mathrm{~kg} / \mathrm{m}^{2}$ in men, and $<5.7 \mathrm{~kg} / \mathrm{m}^{2}$ in women. Results: Low skeletal muscle mass was evident in 82 patients (67\%). Multivariate logistic regression analysis showed that age $>77$ years (odds ratio 3.8; 95\% confidence interval 1.271-11.081, $p=$ $0.017)$, past history of stroke $(3.7 ; 1.080-12.686,0.037)$, and body mass index $<23.5 \mathrm{~kg} / \mathrm{m}^{2}(11.6,4.023-33.186$, $<0.001)$ were independent factors associated with low skeletal muscle mass. Conclusions: Approximately $70 \%$ of acute ischemic stroke patients had low skeletal muscle mass, and older age, past history of stroke, body mass index $<23.5 \mathrm{~kg} / \mathrm{m}^{2}$ were associated with low skeletal muscle mass.

Key words: low skeletal muscle mass, acute ischemic stroke, older age, past history of stroke, body mass index

(Jpn J Stroke 42: 156-161, 2020) 